Indexed by:

Csinta

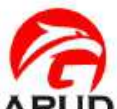

GARUDA

Crossref

Crossmark

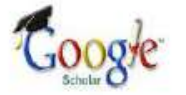

Manuscripts screening tools:

\section{turnitin $\square$}

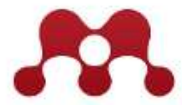

MENDELEY

G grammarly

\title{
STREET EXPERIENCE JALAN BRAGA : MEMAHAMI PEMENUHAN KEBUTUHAN PEJALAN KAKI MELALUI MEDIA GOOGLE STREET VIEW
}

\section{Brian Filbert Pradharma \\ Institut Teknologi Bandung, \\ Bandung, Indonesia \\ Jalan Ganeca No. 10, Lb. Siliwangi, \\ Kecamatan Coblong, Bandung, \\ Indonesia}

\section{Agus Suharjono \\ Ekomadyo}

Institut Teknologi Bandung,

Bandung, Indonesia

Jalan Ganeca No. 10, Lb. Siliwangi

Kecamatan Coblong, Bandung,

Indonesia

Key words:

street experience; walking needs; pedestrian; Google Street View

Doi:

10.17509/jaz.v4i1.29920

Cite article:

Pradharma, B. F., Alnindya, D. T., Aninditya, B., Pourine, M., Ekomadyo, A. S., dan Susanto, V. (2021). Street Experience Jalan Braga : Memahami Pemenuhan Kebutuhan Pejalan Kaki Melalui Media Google Street View. Jumnal Arsitektur Zonasi, 4(1), 46-61. https://oi.org/doi.org/10.17509/jaz.v4i1.29920

\footnotetext{
Akses online:

untuk naskah lengkap tersedia di: https://ejournal.upi.edu/index.php/jaz/issue/archive
}

\author{
Bunga Aninditya Mayang \\ Pourine \\ Institut Teknologi Bandung, \\ Bandung, Indonesia \\ Jalan Ganeca No. 10, Lb. Siliwangi, \\ Kecamatan Coblong, Bandung, \\ Indonesia
}

\section{Vanesa Susanto \\ Institut Teknologi Bandung, Bandung, Indonesia Jalan Ganeca No. 10, Lb. Siliwangi, Kecamatan Coblong, Bandung, Indonesia}


http://ejournal.upi.edu/index.php/jaz - e-mail: jurnal_zonasi@upi.edu doi.org/10.17509/jaz.v4i1.29920

\section{STREET EXPERIENCE JALAN BRAGA : MEMAHAMI PEMENUHAN KEBUTUHAN PEJALAN KAKI MELALUI MEDIA GOOGLE STREET VIEW}

$$
\begin{aligned}
& \text { Article History: } \\
& \text { First draft received: } \\
& 30 \text { November } 2020 \\
& \text { Revised: } \\
& \text { 4 Januari } 2021 \\
& \text { Accepted: } \\
& \text { 11 Januari } 2021 \\
& \text { First online: } \\
& 13 \text { Januari } 2021 \\
& \text { Final proof received: } \\
& \text { Print: } \\
& \text { 1 Februari } 2021 \\
& \text { Online } \\
& 6 \text { Februari } 2021
\end{aligned}
$$

Jurnal Arsitektur ZONASI is indexed and listed in several databases:

SINTA 4 (Arjuna)

GARUDA (Garda Rujukan Digital)

Google Scholar

Dimensions

oneSearch

BASE

\section{Member: \\ Crossref \\ RJI \\ APTARI}

FJA (Forum Jurna Arsitektur)

IAI

AJPKM

\author{
Brian Filbert Pradharma ${ }^{1}$; Diandri Taqia Alnindya ${ }^{2}$; \\ Bunga Aninditya Mayang Pourine ${ }^{3}$; Agus Suharjono Ekomadyo ${ }^{4}$ \\ Vanessa Susanto ${ }^{5}$ \\ 1,2,3,4,5 Institut Teknologi Bandung, Bandung, Indonesia \\ Jl. Ganesha No.10, Lb. Siliwangi, Kecamatan Coblong, Kota Bandung, Jawa Barat \\ 40132 Email: brianpradharma@ gmail.com ; dtalnindyaa@gmail.com : \\ bunganmp@gmail.com; aekomadyo00@gmail.com ; vanessa.susanto911@gmail.com
}

\begin{abstract}
The purpose of this study was to find out how pedestrian needs are met through visual elements of the streetscape to recognize the street experience offered by Braga Street, Bandung. Street is a place where people interact which shapes the aesthetic quality, economic activity, health and sustainability of society. There are 5 levels of needs for pedestrians or the hierarchy of walking needs, namely feasibility, accessibility, safety, comfort, and pleasurability. Braga Street itself has an active frontage form with wide building openings to increase the area's activity. As a heritage area, cultural heritage buildings on Braga Street have been preserved by making this area as tourist destination where the street is the main activities center. The method used is collecting image data of Braga Street via Google Street View and making a checklist of visual elements that can be applied from these aspects. From these findings, it can be concluded that all pedestrian needs based on the visual elements of the streetscape of Braga Street have been fulfilled, but the management still need to be improved to create a better quality of street experience for Braga Street.
\end{abstract}

Keywords: street experience; walking needs; pedestrian; Google Street View

\begin{abstract}
Abstrak: Tujuan dari penelitian ini adalah mengetahui bagaimana kebutuhan pedestrian dipenuhi melalui elemen-elemen visual streetscape untuk mengenali street experience yang ditawarkan Jalan Braga, Bandung. Jalan merupakan tempat dimana orang-orang berinteraksi yang membentuk kualitas estetika, kegiatan ekonomi, kesehatan dan keberlanjutan masyarakat. Terdapat 5 kebutuhan pejalan kaki atau walking needs yaitu feasibility, accessibility, safety, comfort, dan pleasurability. Jalan Braga sendiri memiliki bentuk active frontage dengan bukaan-bukaan bangunan yang lebar untuk meningkatkan keaktifan kawasan. Sebagai kawasan heritage, bangunan-bangunan cagar budaya di Jalan Braga dilestarikan dengan menjadikan kawasan ini sebagai tempat wisata dengan jalan sebagai pusat aktivitas utama Metode yang digunakan adalah pengambilan data gambar Jalan Braga melalui Google Street View dan membuat checklist item elemen visual yang menjadi pengaplikasian dari aspek kebutuhan pejalan kaki. Dari temuan-temuan tersebut, dapat ditarik kesimpulan bahwa semua kebutuhan pejalan kaki berdasarkan elemen-elemen visual streetscape Jalan Braga sudah terpenuhi, namun pengelolaannya dapat ditingkatkan kembali untuk menciptakan kualitas street experience Jalan Braga yang lebih baik.
\end{abstract}

Kata Kunci: street experience; walking needs; pedestrian; Google Street View

\section{Pendahuluan}

Streetscape atau pemandangan jalanan adalah kesatuan dari elemen-elemen visual jalan, yang berupa jalan itu sendiri, bangunan di sekitarnya, trotoar, furniture jalan, pepohonan, ruang-ruang terbuka, yang bergabung menciptakan sebuah karakter jalan. Seiring dengan perkembangannya teknologi berkendara, jalan- 
jalan sekarang dikuasai oleh kendaraan bermotor yang membuat pejalan kaki tidak merasa nyaman dan aman. Pemandangan jalan ini sulit ditangkap oleh pikiran dan perasaan manusia jika jalan dilalui di dalam kendaraan bermotor. Padahal ada pengalaman yang lebih menarik, lebih berharga, lebih bermakna bila jalan dilalui dengan kecepatan perjalanan yang tepat. Dengan berjalan kaki, pengunjung dapat menikmati detail-detail ruang yang ada pada streetscape karena kecepatan pergerakannya dapat ditentukan sendiri, terlebih lagi dapat didukung dengan ruang-ruang berhenti yang menarik. Perlu adanya pengembangan kembali untuk jalan-jalan di area urban, dimana prosesnya berfokus tidak pada kendaraan bermotor, namun pejalan kaki sebagai pengguna jalan utama.

Dengan berjalan kaki, maka kawasan heritage pada suatu kota bisa dinikmati dengan baik. Kawasan heritage ini banyak mengandung cerita bagaimana suatu proses perjalanan sejarah kota (Ekomadyo, 2018, Ekomadyo, dkk, 2018). Kawasan heritage ini, karena kekayaan kandungan warisan budaya bisa menjadi destinasi wisata (Panjaitan, dkk, 2017, Siregar, dkk, 2017). Potensi ini menjadikan jalur-jalur wisata dirancang dengan mengkoneksikan tempat-tempat penting di dalam kota yang punya nilai heritage (Ekomadyo, dkk, 2016, Amalia \& Ekomadyo, 2018). Jalur-jalur koneksi ini akan memberikan pengalaman menarik jika mampu mengakomodasi informalitas yang menghidupkan kawasan (Cesarin, dkk., 2017).

Kawasan heritage di pusat kota selalu memiliki nilai lebih pada streetscape-nya: fungsionalitas, keindahan, nilai sejarah, primadona kota tersebut. Namun kepadatan kota yang bertambah setiap tahunnya menambahkan jumlah kendaraan yang akhirnya mengurangi kualitas pengalaman jalan yang dimaksud oleh desainernya. Kota Bandung terkenal sebagai pusat kota baru pemerintahan penjajahan Belanda. Pembangunannya didasarkan pada ketidakinginan terjadinya pengulangan kesalahan yang pernah dilakukannya pada kota-kota yang didirikannya di Indonesia. Perencanaan Kota Bandung oleh Belanda sangat baik dan indah, dihiasi dengan bangunan-bangunan dengan beragam langgam arsitektur yang memperkaya jalan-jalan yang telah dibuat. Pemerintahan Belanda di Indonesia telah memberikan usaha yang besar, indah, dan agung dalam menciptakan wajah kota yang baru. Nilai keindahan yang telah berkembang menjadi nilai historis ini perlu diingat, disebarkan keberadaannya, dan dirawat dengan sepenuh hati. Dengan peningkatan ruang-ruang pedestrian pada jalan-jalan di Kota Bandung, para pengunjung tidak akan pergi dengan pengalaman jalan yang biasa-biasa saja. Pengalaman ruang jalan sudah seharusnya menjadi fokus utama setiap pengembangan jalan bukan lagi pada akses dan sirkulasi kendaraan bermotor semata. Salah satunya adalah Jalan Braga di Kota Bandung. Jalan dengan nilai historis yang tinggi karena arsitektur di sepanjang bentangnya perlu menjadikan street experience-nya sebagai aset utama pengembangan kawasan sebagai tempat wisata.

Dalam menciptakan pengalaman jalan yang baik, perlu dipenuhi terlebih dahulu kebutuhan-kebutuhan pejalan kaki. Menurut Alfonzo (2005), kebutuhan ini dirumuskan ke dalam sebuah hierarki dengan 5 tingkat yaitu feasibility, accessibility, safety, comfort, dan pleasurability. Untuk mencapainya, jalanan perlu memiliki active frontage yang menghidupkan street experience di Jalan Braga. Penelitian ini memiliki pertanyaan penelitian yaitu bagaimana kebutuhan pejalan kaki dipenuhi melalui elemen-elemen visual streetscape Jalan Braga. Oleh karena itu, tujuan penelitian adalah untuk melihat pengalaman berjalan di Jalan Braga melalui sisi kelengkapan kebutuhan pejalan kakinya.

Penelitian dilakukan dengan menggunakan Google Street View untuk menciptakan warna baru dalam ranah penelitian arsitektur di Indonesia dengan mengeksplorasi big data. Fotografi telah digunakan bertahuntahun sebagai representasi grafis ruang untuk analisis dan desain. Namun dimana kini, Google Street View dapat memberikan lebih banyak informasi dan fleksibilitas bila dibandingkan dengan fotografi yang merupakan cara representasi tradisional.

Penelitian serupa telah dilakukan oleh Rundle yang menyarankan penggunaan Google Street View karena dinilai lebih efektif untuk mengaudit lingkungan jalan yang dapat dilalui dengan berjalan kaki. Penelitian mereka menunjukkan tingkat ketepatan yang tinggi antara pengukuran berdasarkan audit dari lapangan dan dari Google Street View (Rundle et al., 2011).

\subsection{Kajian Literatur \\ To Walk or Not To Walk}

Kebutuhan dari pejalan kaki dirumuskan oleh Alfonzo (2005) dengan konsep hierarki yang terdiri dari 5 tingkat (gambar 1). Tingkat yang pertama harus terpenuhi terlebih dahulu untuk memenuhi tingkat selanjutnya hingga seluruh kebutuhan pejalan kaki terpenuhi. Kelima tingkat tersebut menunjukkan adanya keberagaman individu, kelompok, regional, dan faktor-faktor lingkungan fisik. Pengambil kebijakan perlu memperhatikan keadaan dan populasi serta mengadopsi pendekatan multilevel untuk memprogramkan intervensi yang bertujuan untuk meningkatkan aktivitas berjalan kaki 
Tingkat pertama adalah feasibility atau kelayakan yang didasarkan pada tiga faktor yaitu mobilitas, waktu, dan tanggung jawab. Kelayakan ini dapat diteliti melalui jumlah orang dewasa dan anak dalam rumah tangga, tanggung jawab perawatan anak, serta umur, kesehatan, dan kemampuan mobilitas fisik pejalan kaki. Tingkat ini bersifat internal yang artinya tidak dipengaruhi oleh streetscape jalan.

Tingkat yang kedua adalah accessibility atau aksesibilitas dengan faktor-faktor antara lain adalah pola, kuantitas, kualitas, keberagaman, dan proximity aktivitas-aktivitas yang ada, konektivitas antara fungsi, dan infrastruktur yang berkaitan dengan pejalan kaki. Aksesibilitas dapat dioperasikan melalui ada dan lengkapnya jaringan trotoar, adanya pembatas-pembatas, serta jarak dan jumlah destinasi pada jalan.

Tingkat yang ketiga adalah safety atau keselamatan yang dipengaruhi oleh karakteristik desain urban yang berkaitan dengan ruang yang tidak mendukung dan ketakutan akan terjadinya tindakan kriminal, jenisjenis penggunaan lahan, dan kehadiran orang-orang. Keselamatan dapat diteliti melalui keberadaan grafiti, sampah, bangunan tidak terpakai, dan jendela-jendela pada lantai satu, bar, dan kelompok atau orang-orang yang berpotensi mengganggu.

Tingkat keempat adalah comfort atau kenyamanan yang memiliki tiga faktor, yaitu karakteristik desain urban yang mempengaruhi hubungan antara pejalan kaki dan kendaraan bermotor, sistem jalan pejalan kaki dan jaringan jalan, dan fasilitas urban. Kenyamanan dapat dilihat dari keberadaan fitur-fitur pereda lalu lintas (seperti bundaran, median, lampu jalan), lebar jalan, panjang blok, lebar trotoar, adanya buffer trotoar, pepohonan, furniture jalan, arcade, kanopi, air mancur, dan lain-lain.

Tingkat terakhir adalah pleasurability atau kenikmatan dipengaruhi oleh keragaman dan kompleksitas, keaktifan, skala dan koherensi arsitektural, estetika. Kenikmatan ini hadir melalui keberagaman streetscape, fungsi campuran, elemen-elemen arsitektural, arsitektur unik atau historis, ruang-ruang publik, keberadaan orang-orang, vendor jalan atau pedagang kaki lima, atau area makan di luar.

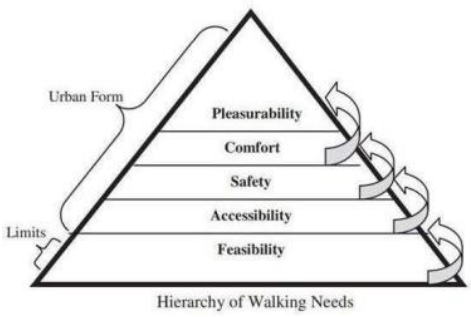

Gambar 1. Hierarki Kebutuhan Pejalan Kaki

(Sumber: Alfonzo, 2005)

\section{Active Frontage Dalam Jalur Pedestrian}

Istilah pedestrian berakar dari bahasa latin 'pedestres' yang berarti orang yang berjalan kaki. Pedestrian adalah pergerakan atau perpindahan manusia dari suatu tempat ke titik asal menuju ke tempat lain yang menjadi tujuan dari pergerakan dengan berjalan kaki (Rubenstein,1992). Berjalan kaki membutuhkan suatu ruang yang dikenal sebagai jalur pedestrian. Jalur pedestrian adalah ruas pejalan kaki, baik yang terintegrasi maupun terpisah dengan jalan, yang diperuntukkan sebagai sarana dan prasarana pejalan kaki serta menghubungkan pusat-pusat kegiatan dan/atau fasilitas pergantian moda. Namun, proses berjalan kaki bukan hanya sekedar perpindahan linear dari satu tempat ke tempat lain. Pejalan kaki dapat berhenti untuk berganti arah, bermanuver, mempercepat langkah, memperlambat langkah atau berganti ke aktivitas lain seperti duduk, berlari, dan berbaring. Menurut Gehl (2010) dalam bukunya yang berjudul Life Between Buildings, "life takes place on foot". Lebih dari sekedar transportasi, proses berjalan kaki menangkap kehidupan di dalam kota.

Area frontage yang 'aktif' dapat menambah minat, kehidupan, dan vitalitas ke ranah publik. Rangkaian area frontage yang ditata baik akan mengundang pejalan kaki bergerak masuk ke dalam fungsi bangunan. Beberapa hal yang dapat dilakukan untuk menciptakan active frontage pada jalur pedestrian antara lain memperbanyak bukaan pada bangunan dan mengurangi adanya 'blank walls', merancang fasad bangunan sehingga menciptakan artikulasi yang menyambut pejalan kaki, dan menyediakan area outdoor pada bangunan yang terkesan 'tumpah' ke jalan sehingga memberikan kehidupan secara langsung pada jalur pedestrian. Bukaan-bukaan pada bangunan yang dapat memperlihatkan aktivitas yang terjadi di dalam bangunan dapat menarik minat dan memberikan experience pada pejalan kaki yang lewat. Sebaliknya, pengguna bangunan juga dapat melihat ke luar sehingga berkontribusi pada keselamatan yang dikenal dengan istilah 'eyes on the street'. Adanya kanopi, balkon, beranda, atau proyeksi lainnya di bagian depan bangunan dapat mengundang pejalan kaki untuk masuk ke dalam bangunan. Hal ini seperti analogi loket tiket pada teater atau area resepsi pada kantor, dimana area tersebut merupakan area penyambut tamu yang kemudian akan diarahkan untuk masuk ke dalam teater atau ruangan dalam kantor tersebut. Penyediaan area outdoor selain memberikan 
kehidupan pada jalan, juga membuat jalur pedestrian menyenangkan dan menarik bagi penggunanya. Mereka dapat menikmati experience yang tercipta dari fitur-fitur urban dan elemen arsitektural serta menyaksikan berbagai aktivitas menarik di sepanjang jalan.

\section{Bangunan Heritage sebagai Elemen Streetscape}

Streetscape atau wajah jalan menurut adalah istilah yang digunakan untuk menggambarkan kondisi alam dan jalan yang dibangun dan didefinisikan sebagai kualitas desain jalan dan efek visualnya. Streetscape perkotaan memainkan peran penting dalam pengembangan kehidupan perkotaan (Crankshaw, 2015). Dalam streetscape, jalan merupakan ruang publik dimana masyarakat dapat terlibat dalam berbagai aktivitas. Jalan menjadi tempat dimana orang-orang berinteraksi yang pada akhirnya membentuk kualitas estetika, kegiatan ekonomi, kesehatan dan keberlanjutan masyarakat. Menurut Kogarah City Council (2006) dan Carmona, et al (2003), elemen pembentuk karakter streetscape terdiri dari elemen fisik dan nonfisik. Elemen fisik pembentuk karakter streetscape terdiri dari geometri dan bentuk jalan, proporsi dan keterlingkupan, karakter bangunan, serta karakter vegetasi. Sedangkan elemen non fisik merupakan karakter aktivitas yang meliputi fungsi atau aktivitas formal di dalam bangunan, aktivitas informal di luar bangunan, serta aktivitas khusus atau insidental. Karakter bangunan merupakan salah satu elemen fisik streetscape yang penting karena perannya sebagai pemberi kesan pada ruang jalan.

Dalam Rencana Detail dan Tata Ruang Kota Bandung pasal 50, Jalan Braga termasuk dalam zona cagar budaya. "Heritage building is a group of separate or connected buildings, which because of their architecture, their homogeneity or their place in landscape, are of outstanding universal value from the point of view of history, art or science" menurut UNESCO. Bangunan heritage adalah bangunan yang memiliki corak khas atas tradisi suatu budaya yang digunakan secara terus menerus dan dijadikan ciri khas. Bangunan heritage sangat mengandung nilai penting unsur kebudayaan. Bangunan ini memiliki nilai estetik dari eksterior maupun interiornya, nilai spiritual dimana ia memiliki posisi penting dalam suatu kepercayaan, nilai sosial dari penciptaaan ikatan dalam komunitas dan unsur landmark suatu tempat, nilai sejarah sebagai bukti yang masif tentang suatu peradaban manusia, nilai simbolis dalam mewakili status sosial dari masyarakat tertentu, nilai otentik dari keaslian bentuk interior dan eksterior sehingga menciptakan suatu keunikan. Semua nilai-nilai tersebut menyumbangkan nilai lebih untuk individu maupun komunitas terkait (Hernowo, 2015). Sehingga, bangunan cagar budaya yang membentuk streetscape pada Jalan Braga memberikan keunikan, ketertarikan dan nilai lebih dalam experience jalan tersebut.

\section{Metode Penelitian}

Google Street View (GSV) menyajikan panorama pemandangan jalan yang sama dengan pemandangan aslinya namun disajikan dalam bentuk web interaktif. Panorama Google Street View adalah gambar $360^{\circ}$ yang dihasilkan dari delapan gambar asli yang ditangkap oleh delapan kamera horizontal pada satu titik kemudian digabungkan menjadi satu gambar panorama (Tsai dan Chang, 2012). Gambar Panorama Google Street View memiliki cakupan horizontal $360^{\circ}$ dan cakupan vertikal $180^{\circ}$. Setiap gambar Google Street View yang tersedia dapat diminta dalam bentuk HTTP URL menggunakan Google Street View Image API bersama dengan posisi mobil Google Street View dan arah pergerakannya. Dengan menentukan parameter URL dikirim melalui permintaan HTTP standar menggunakan Google Street View Image API, pengguna bisa mendapatkan gambar Google Street View statis ke segala arah dan di setiap sudut untuk setiap titik di mana Google Street View tersedia. Cakupan GSV yang komprehensif membuatnya berguna untuk kebutuhan navigasi sehari-hari, dan peta topografi yang beragam mendorong inovasi, eksperimentasi, dan eksplorasi pengguna. Sebagai representasi spasial, metode ini menyatukan dua cara berbeda untuk mengetahui dunia melalui dokumentasi empiris: pemetaan dan fotografi. Sementara peta menawarkan diagram visual informasi spasial, foto menawarkan dokumen dengan kualitas spasial spesifik. Gambar spasial ini menjadi mode navigasi dan eksplorasi (Gilge, 2016). Google Street View diperbarui secara berkala. Untuk penelitian ini kami menggunakan foto tahun 2019, diunduh tanggal 26 Oktober 2020.

Untuk merepresentasikan street experience kami menggunakan 35 titik foto di sepanjang jalan braga. Tiap titik foto berjarak sekitar 11 meter. Gambar 2 mengilustrasikan hasil unduh gambar Google Street View untuk satu blok jalan. Satu blok jalan dapat memiliki sejumlah lokasi pengambilan gambar di sepanjang jalan, seperti yang ditandai dengan "x" pada gambar. Semua gambar Panorama pada jalan perlu diunduh. Pengunduhan dimulai dari koordinat titik awal jalan untuk panorama pertama dan kemudian pindah ke lokasi yang berdekatan di sepanjang jalan untuk mengunduh gambar panorama yang sesuai dengan urutannya hingga akhir dari jalan. 
Bagian tengah Gambar 2 menunjukkan contoh gambar panorama yang diunduh untuk salah satu lokasi pemotretan (ditandai dengan " $x$ " yang dicetak tebal) di jalan. Gambar panorama ini mungkin memberi kesan kepada persimpangan jalan karena setiap sisi jalan merupakan setengah dari lingkaran panorama dengan tampilan perspektif. Gambar 2 menutupi sisi bawah jalan dan menunjukkan apa yang dilihat seseorang di " $x$ " yang dicetak tebal dengan rentang tampilan vertikal $90^{\circ}$ di bagian atas, $0^{\circ}$, dan minus $90^{\circ}$ di bawah, serta rentang tampilan horizontal $0^{\circ}$ di kiri, $180^{\circ}$ di tengah, dan $360^{\circ}$ di kanan (Yin et al., 2015).

Panorama seperti yang ditunjukkan pada baris kedua Gambar 2 digunakan untuk mendeteksi keberadaan checklist item pada tabel 1. Akan tetapi, gambar kurang diinginkan karena distorsi gambar dari tampilan perspektif. Seperti yang ditunjukkan pada Gambar 2, bagian dengan distorsi terkecil berada di tengah gambar kiri dan kanan. Jadi, kami menggambar kotak di tengah setiap sisi lingkaran panorama untuk membuat gambar yang ditampilkan di bagian bawah. Ukuran kotak didasarkan pada informasi tentang jarak rata-rata antara setiap lokasi pemotretan yang berdekatan pada blok jalan, dan sudut pandang horizontal rata-rata $(\alpha)$ yang memungkinkan untuk melihat keseluruhan blok jalan dirata-ratakan dari setiap posisi pemotretan. Panorama yang telah diunduh kemudian diubah menjadi gambar dengan tampilan sisi jalan, digunakan untuk mendeteksi keberadaan checklist item pada tabel 1. Dua gambar dibuat untuk setiap lokasi pemotretan, yang masingmasing dapat dirangkai bersama dengan gambar lain dari blok jalan yang sama untuk membuat suatu rangkaian foto untuk setiap sisi blok jalan.

Metode ini memiliki ketidaksempurnaan berupa beberapa titik gambar yang tertutup mobil sehingga item tidak dapat ditilik keberadaannya. Bagian jalan yang pada gambar tertutup mobil dianggap tidak memiliki item yang ditilik. Untuk melengkapi data, kami juga mengumpulkan gambar pada fitur Photos Google Maps yang merupakan kumpulan foto yang diunggah pengguna Google Maps. Gambar-gambar ini kami gunakan untuk mengecek item-item yang tidak terlihat secara eksplisit.

Beberapa penelitian dengan pengambilan data dari GSV yang dilakukan oleh Gilge (2016) dan Tsai \& Chang (2012) menunjukkan betapa signifikannya pengalaman visual yang dihadirkan GSV untuk mencukupi kebutuhan navigasi dan eksplorasi pengguna, termasuk peran gambar fotografi dalam menentukan lokasi, inventaris infrastruktur dan rambu, hingga pengalaman imersif dalam menjelajahi kota secara virtual. Pemanfaatan GSV bisa menjadi alternatif metode dalam mencari tahu peran penting teknik fotografi spasial dan visual dalam mengidentifikasi sebuah lokasi serta lingkungan di sekitarnya dalam skala global.

Pemotongan gambar 360 GSV menyebabkan distorsi sehingga digunakan untuk analisis penulis semata, dengan asumsi bahwa objek yang menjadi indikator tidak berubah, maka gambar pada bagian pembahasan diganti dengan pengambilan gambar yang tidak diunduh langsung dari Google Street View, namun merupakan hasil screenshot dengan sudut pengambilan gambar yang tidak menciptakan distorsi.

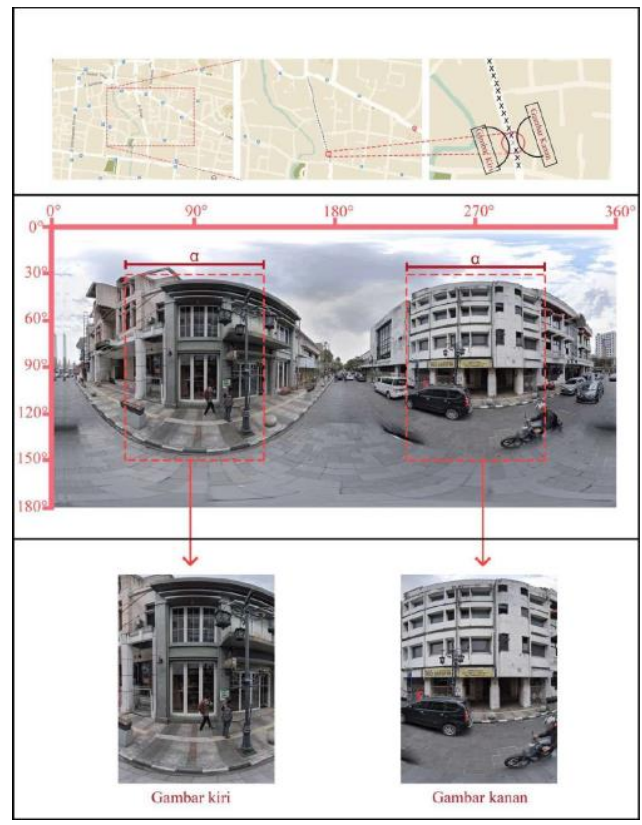

Gambar 2. Metode

Sumber: Analisis Penulis, 2020 


\section{Hasil dan Pembahasan}

\subsection{Batasan Penelitian}

Penelitian dilakukan di Jalan Braga, Kecamatan Sumur Bandung, Kota Bandung dengan batasan persimpangan Jalan Braga, Jalan Suniaraja, dan Jalan Lembong di bagian utara dan persimpangan Jalan Braga dan Jalan Naripan di bagian Selatan (Gambar 3).

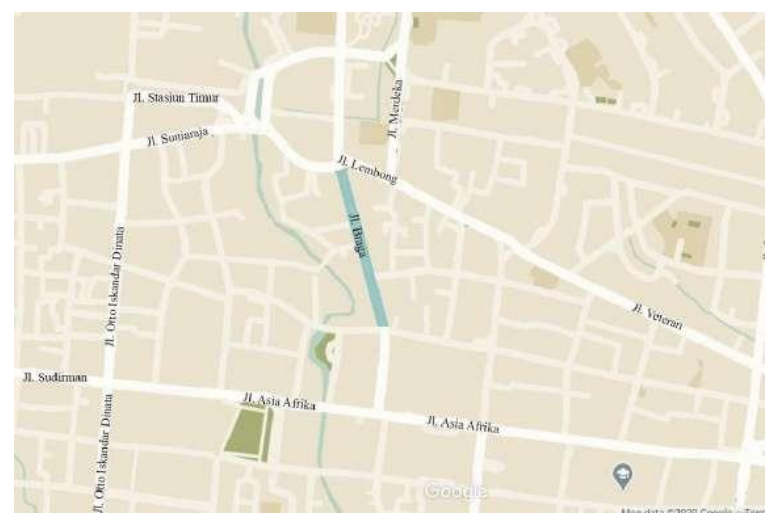

Deliniasi:

Gambar 3. Batasan Penelitian

Sumber: Google Maps, 2020

Batas Utara: persimpangan Jl. Braga, Jl. Suniaraja, dan Jl. Lembong

Batas Selatan: persimpangan Jl. Braga dan Jl. Naripan

Lebar jalan: 7.5 meter

Lebar trotoar: 2 meter

Tinggi trotoar: $15 \mathrm{~cm}$

\subsection{Street Experience Jalan Braga Berdasarkan Indikator Walking Needs}

Menurut Alfonzo (2005), 5 tingkat aspek kebutuhan pejalan kaki adalah feasibility, accessibility, safety, comfort, dan pleasurability. Feasibility tidak diteliti karena merupakan tingkat yang bersifat internal dari pejalan kaki dan tidak berkaitan dengan desain ruang jalan dan elemen-elemen fisiknya. Melalui gambar yang didapatkan dari Google Street View, diidentifikasi item-item yang merupakan pengaplikasian keempat aspek kebutuhan pejalan kaki tersebut.

Tabel 1. Checklist Item

\begin{tabular}{|c|c|c|c|}
\hline Aspek & Faktor & Pengaplikasian & Item \\
\hline \multirow[t]{4}{*}{$\begin{array}{l}\text { Accessibility/ } \\
\text { aksesibilitas }\end{array}$} & $\begin{array}{l}\text { Pola, kuantitas, kualitas, } \\
\text { keberagaman, dan proximity } \\
\text { dari aktivitas-aktivitas yang } \\
\text { terjadi }\end{array}$ & $\begin{array}{l}\text { Kehadiran atau kelengkapan } \\
\text { trotoar }\end{array}$ & $\begin{array}{l}\text { Kontinuitas jalur pedestrian } \\
\text { yang ditandai dengan tidak } \\
\text { terputusnya pemakaian } \\
\text { material jalan }\end{array}$ \\
\hline & Konektivitas & $\begin{array}{l}\text { Kehadiran atau jumlah } \\
\text { pembatas, penggunaan lahan } \\
\text { (dengan gerbang pemisah), } \\
\text { fitur alami, } \\
\text { atau pembatasan secara } \\
\text { psikologis (jalan yang lebar) }\end{array}$ & Jeda pada persimpangan jalan \\
\hline & \multirow{2}{*}{$\begin{array}{l}\text { Infrastruktur yang berkaitan } \\
\text { dengan pejalan kaki }\end{array}$} & Jarak ke destinasi & Panjang jalan \\
\hline & & Jumlah destinasi & Toko-toko, anchor \\
\hline \multirow[t]{3}{*}{$\begin{array}{l}\text { Safety } \\
\text { /keselamatan }\end{array}$} & $\begin{array}{l}\text { Fitur-fitur dari bentuk urban } \\
\text { yang dapat berkontribusi } \\
\text { pada rasa aman }\end{array}$ & $\begin{array}{l}\text { Kehadiran grafiti, sampah, } \\
\text { bangunan tidak terpakai, jendela } \\
\text { pada lantai } 1 \text { bangunan }\end{array}$ & $\begin{array}{ll} & \text { Graffiti } \\
\circ & \text { Sampah } \\
\circ & \text { Bangunan tidak terpakai } \\
\circ & \text { Bukaan pada bangunan }\end{array}$ \\
\hline & Penggunaan lahan & Kehadiran bar, pegadaian, dll. & Fungsi bangunan pada jalan \\
\hline & $\begin{array}{l}\text { Kehadiran kelompok- } \\
\text { kelompok maupun individu } \\
\text { tertentu }\end{array}$ & $\begin{array}{l}\text { Kehadiran individu yang } \\
\text { mengancam dan berkeliaran, dll. }\end{array}$ & $\begin{array}{ll}\circ \text { Keberadaan individu } \\
\text { yang meresahkan } \\
\circ \text { Pengamen } \\
\circ \text { Gelandangan }\end{array}$ \\
\hline
\end{tabular}




\begin{tabular}{|c|c|c|c|}
\hline Aspek & Faktor & Pengaplikasian & Item \\
\hline \multirow[t]{3}{*}{$\begin{array}{l}\text { Comfort } \\
\text { /kenyamanan }\end{array}$} & $\begin{array}{l}\text { Karakter desain urban yang } \\
\text { menunjukkan hubungan } \\
\text { antara pedestrian dan } \\
\text { kendaraan bermotor }\end{array}$ & $\begin{array}{l}\text { Kehadiran fitur-fitur pereda lalu } \\
\text { lintas (seperti bundaran, median, } \\
\text { lampu jalan }\end{array}$ & $\begin{array}{ll}\circ & \text { Beton bollard bulat } \\
\circ & \text { Tekstur pembeda } \\
& \text { trotoar dan jalan } \\
\circ & \text { Tinggi pedestrian } \\
\end{array}$ \\
\hline & $\begin{array}{l}\text { Karakteristik desain terkait } \\
\text { dengan sistem jalur pejalan } \\
\text { kaki dan jaringan jalan. }\end{array}$ & $\begin{array}{l}\text { Lebar jalan, panjang blok, lebar } \\
\text { trotoar, kehadiran buffer trotoar, } \\
\text { dan pepohonan. }\end{array}$ & $\begin{array}{ll} & \text { Lebar jalan } \\
\circ & \text { Lebar trotoar } \\
\circ & \text { Sidewalk Buffer } \\
\circ & \text { Pohon }\end{array}$ \\
\hline & $\begin{array}{l}\text { Keberadaan fasilitas jalan } \\
\text { yang mempengaruhi } \\
\text { kenyamanan }\end{array}$ & $\begin{array}{l}\text { Furniture jalan, arcade, kanopi, } \\
\text { air mancur, dll. }\end{array}$ & $\begin{array}{ll} & \text { Furniture jalan } \\
\circ & \text { Lampu jalan } \\
\circ & \text { Arcade } \\
\circ & \text { Kanopi }\end{array}$ \\
\hline \multirow[t]{3}{*}{$\begin{array}{l}\text { Pleasurability } \\
\text { /kenikmatan }\end{array}$} & $\begin{array}{l}\text { Keragaman dan } \\
\text { kompleksitas }\end{array}$ & $\begin{array}{l}\text { Kehadiran variasi streetscape, } \\
\text { fungsi campuran, elemen-elemen } \\
\text { arsitektural, arsitektur historis } \\
\text { atau unik, warna, dll. }\end{array}$ & $\begin{array}{l}\text { Bangunan historis (arsitektur } \\
\text { historis) }\end{array}$ \\
\hline & Keaktifan & Kehadiran ruang publik & Trotoar sebagai ruang publik \\
\hline & $\begin{array}{l}\text { Skala dan koherensi } \\
\text { arsitektural }\end{array}$ & $\begin{array}{l}\text { Kehadiran orang lain, vendor } \\
\text { jalan, ruang makan outdoor, dll. }\end{array}$ & $\begin{array}{l}\text { Pedagang kaki lima } \\
\circ \text { Restoran yang memiliki } \\
\text { area outdoor }\end{array}$ \\
\hline
\end{tabular}

\subsubsection{Aksesibilitas}

Aksesibilitas adalah derajat kemudahan dicapai oleh orang, terhadap suatu objek, pelayanan maupun lingkungan. Pola, kuantitas, kualitas, keberagaman, dan proximity dari aktivitas-aktivitas yang ada; konektivitas antara fungsi; dan infrastruktur yang berkaitan dengan pejalan kaki adalah faktor-faktor dalam aksesibilitas. Ketercapaian aspek ini dapat dilihat melalui lengkapnya jaringan trotoar, adanya pembataspembatas, serta jarak dan jumlah destinasi pada jalan.

Trotoar di sepanjang area penelitian memiliki kontinuitas yang konsisten. Faktor yang menyebabkan adanya jeda di sepanjang trotoar adalah keberadaan persimpangan jalan. Trotoar di sebelah barat jalan terus menerus dari batas utara hingga selatan. Walaupun terdapat gang kecil, yaitu Gang Cikapundung, namun keberadaan gang ini tidak memutus kontinuitas trotoar di sebelah barat karena tekstur dari trotoar tidak terputus. Sedangkan, trotoar di sebelah timur jalan ini sempat terputus karena adanya persimpangan Jalan Kejaksaan (Gambar 4,5, dan 6)

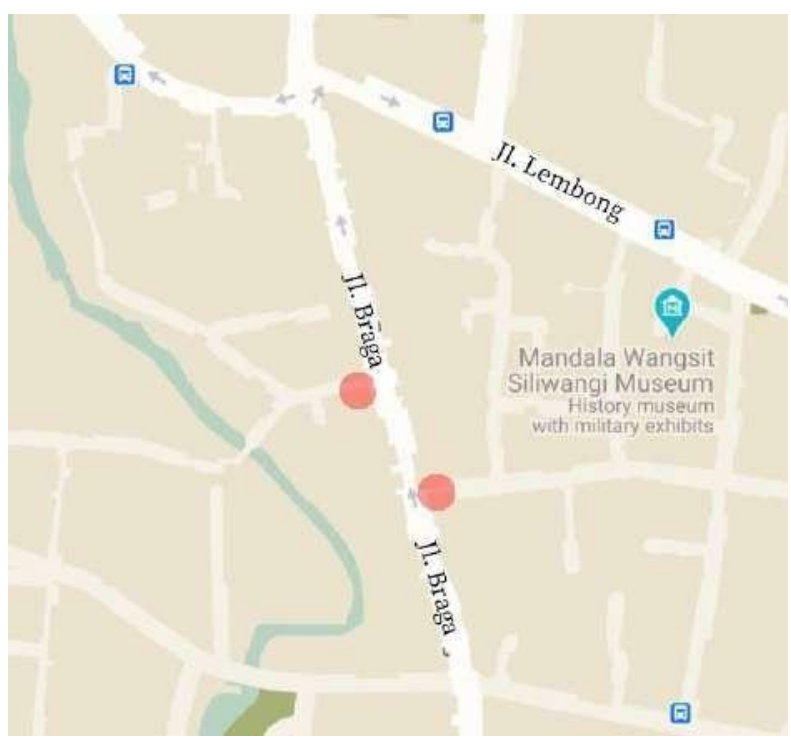

Gambar 4. Gang Cikapundung (sebelah barat) dan Persimpangan Jalan Kejaksaan (sebelah timur) Sumber: Google Maps, 2020 


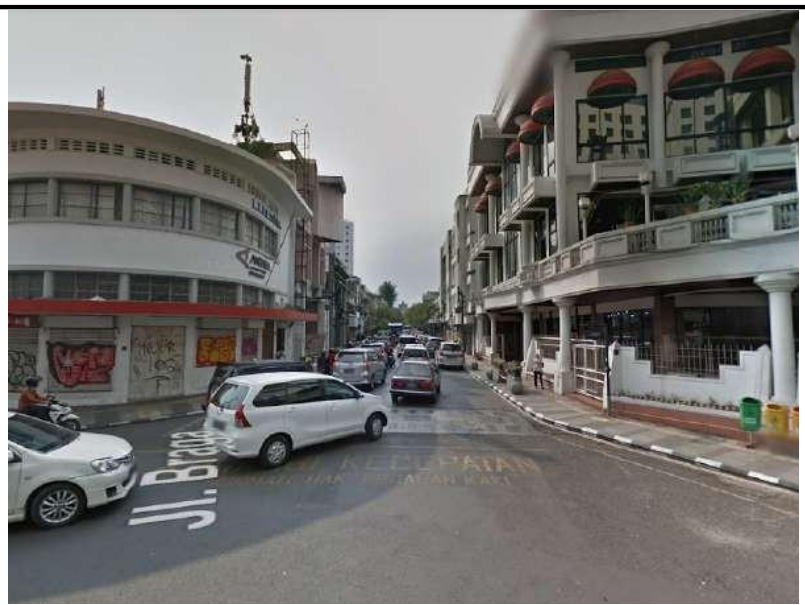

Gambar 5. Batas Jalan Sebelah Selatan (Persimpangan Jalan Naripan) Sumber: Google Street View, 2019

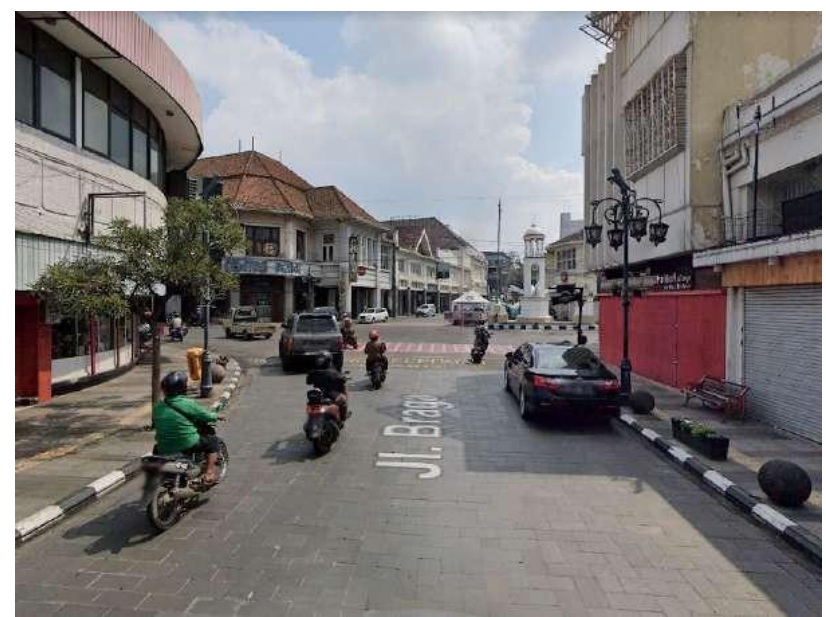

Gambar 6. Batas Jalan Sebelah Utara (Persimpangan Jalan Suniaraja dan Jalan Lembong) Sumber: Google Street View, 2019

Selain itu, trotoar di sepanjang jalan ini memiliki level ketinggian yang berbeda dari lajur jalan kendaraan dan memiliki pembatas berupa kanstin dengan warna hitam putih sehingga memudahkan pejalan kaki untuk membedakan area pedestrian dan kendaraan. Jeda pada persimpangan Jalan Kejaksaan memiliki batasan dan tanda yang jelas pada guiding block berupa simbol titik-titik untuk memberi tanda kepada pengguna jalan (khususnya penyandang tunanetra) perlu berhenti dan mengamati keadaan di sekelilingnya. titik titik yang menandakan berhenti. Pada jeda trotoar tidak ditemukan adanya ramp maupun zebra cross untuk penyeberangan satu jalur trotoar sehingga dapat menyulitkan pergerakan difabel (Gambar 7 dan 8).

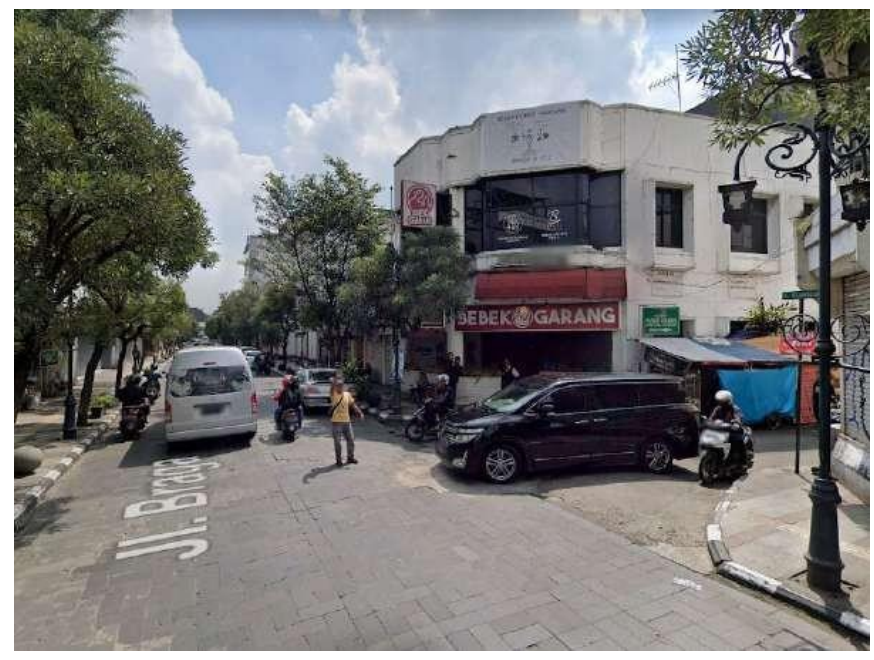

Gambar 7. Persimpangan Jalan Kejaksaan

Sumber: Google Street View, 2019 

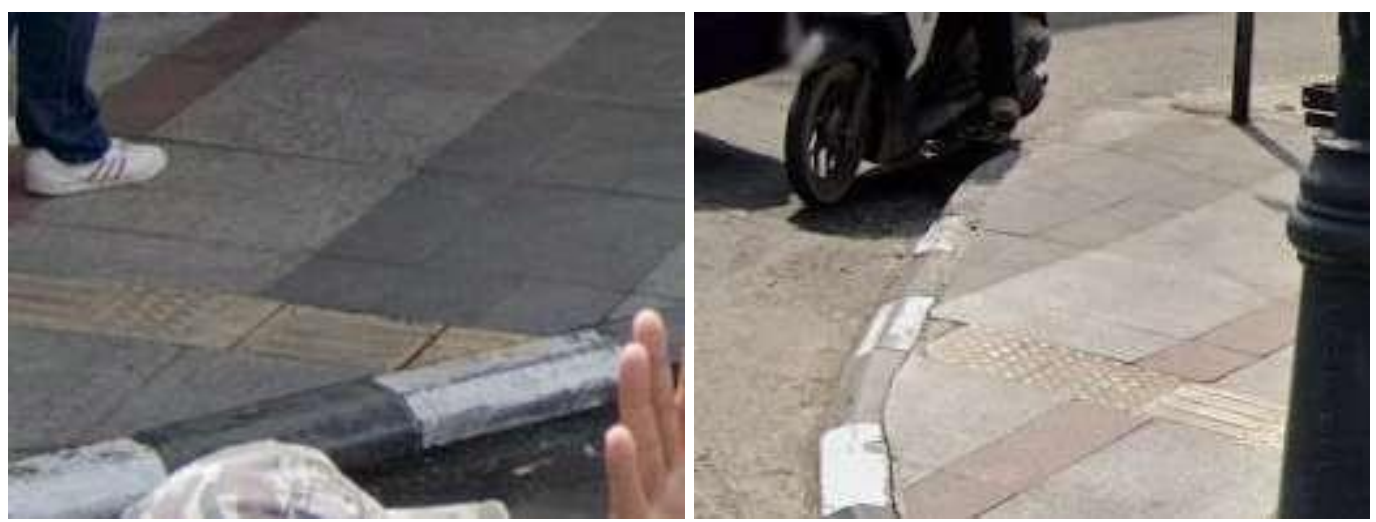

Gambar 8. Pembatas Pada Jeda Trotoar Sumber: Google Maps, 2020

\subsubsection{Safety}

Keselamatan adalah perasaan aman seseorang dari ancaman kejahatan. Keselamatan dapat dipengaruhi oleh bentuk urban, penggunaan lahan, dan kehadiran kelompok-kelompok maupun individu yang mempengaruhi perasaan aman pejalan kaki. Fitur-fitur dari bentuk urban yang dapat berkontribusi pada rasa aman antara lain adalah grafiti, sampah, bangunan-bangunan tidak terpakai. Keberadaan tiga fitur tersebut memiliki hubungan dengan adanya peningkatan kriminalitas (Perkins et al., 1992)

Fitur bentuk urban berupa grafiti terdapat pada 19 bangunan di Jalan Braga yang biasanya ditemukan pada pintu lipat besinya. Keberadaan grafiti dapat dihindari dengan penggunaan pintu lipat besi yang berongga (Gambar 9).

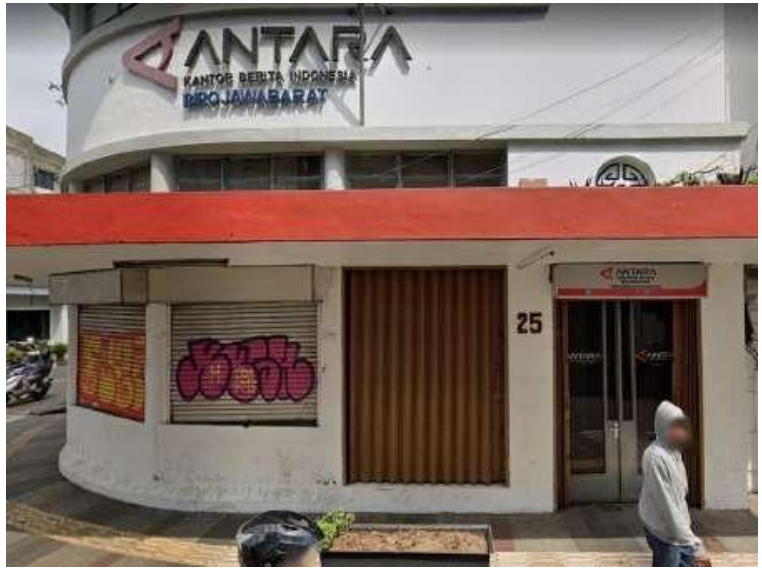

(a)

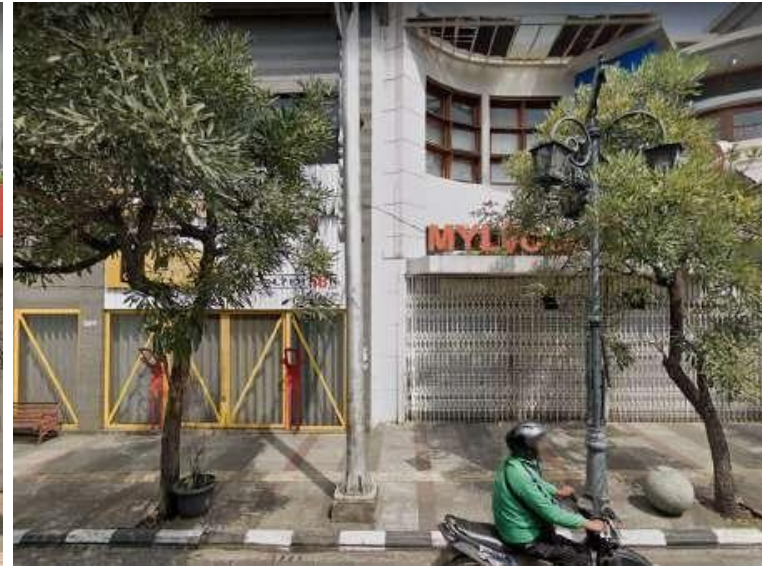

(b)

Gambar 9. Pintu Lipat Besi (a) Dicoreti Grafiti, (b) Berongga

Sumber: Google Street View, 2019

Jalan Braga relatif bersih karena sampah di trotoar hampir tidak ditemukan. Tidak ada gundukan sampah yang terlihat dan sampah yang ditemukan hanya berupa daun-daun kering atau terjatuh dengan tidak sengaja. Namun, pot kotak yang ada di sepanjang jalan pedestrian terkadang dijadikan tempat pembuangan sampah. Sehingga akan lebih baik jika tanaman pada pot-pot ini memiliki volume yang menutup semua bagian atas pot untuk mencegah hal tersebut.

Menurut penggunaan lahan, terdapat 20 bangunan tidak terpakai di Jalan Braga akibat sedang direnovasi, dalam masa dicarikan penyewa atau pembeli, dan terbengkalai. Jalanan yang sempit dan kehadiran properti non residensial dan pertokoan telah dihubungkan dengan tingkat kriminalitas (Perkins et al., 1992) Dari pernyataan tersebut, daerah depan bangunan-bangunan ini dapat berpotensi memunculkan tindakan kriminal. Sementara, bangunan lainnya yang memiliki beragam fungsi, seperti restoran, cafe dan toko-toko di Jalan Braga menggunakan bukaan-bukaan kaca yang lebar untuk memberikan visual akses ke dalam toko (Gambar 10). 


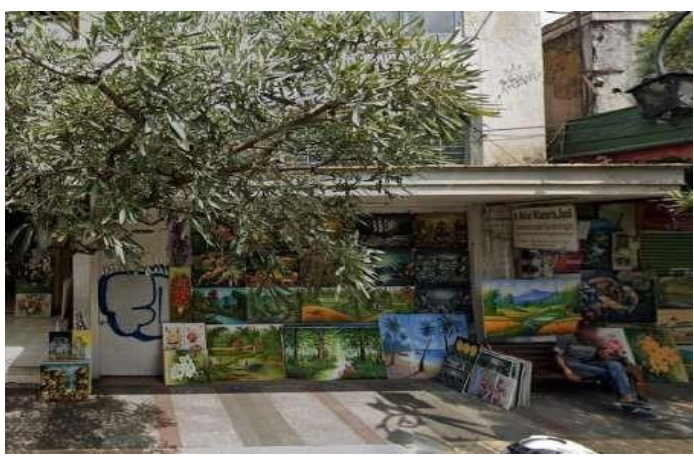

(a)

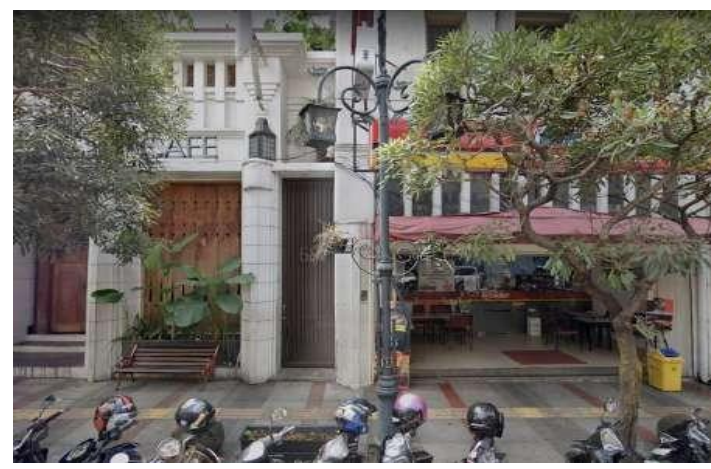

(c)

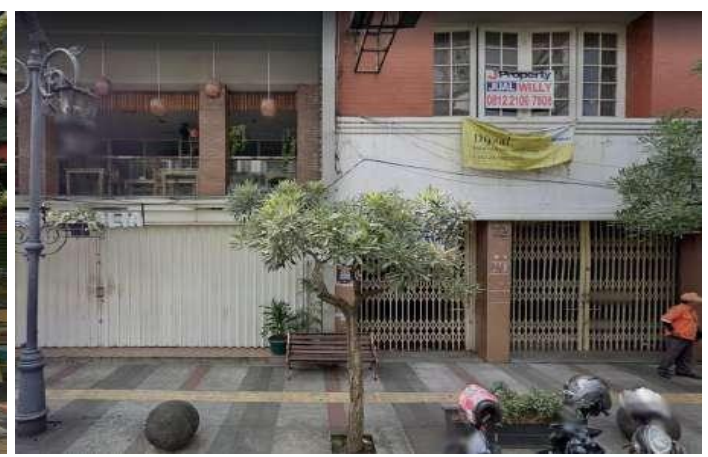

(b)

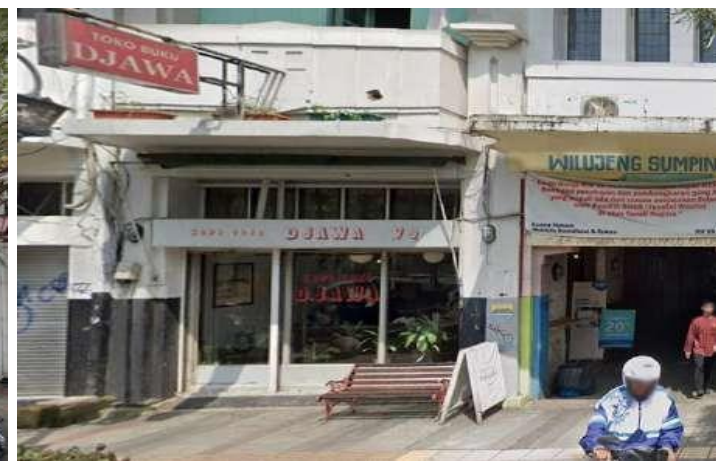

(d)

Gambar 10. Penggunaan Lahan (a) Area Depan Bangunan Tidak Terpakai Menjadi Tempat Berjualan Lukisan, Bangunan Disewakan, (c) Jendela Minimarket, dan (d) Jendela Sebuah Cafe.

Sumber: Google Street View, 2019

Dilihat dari cara berpakaian para pejalan kaki pada gambar Google Street View, pengamen dan gelandangan tidak ditemukan di sepanjang Jalan Braga. Penyandang tunanetra juga tidak terlihat, sehingga guiding block di sepanjang Jalan Braga tidak diketahui keberhasilannya. Kehadiran perkumpulan sekelompok pria sering dipersepsikan dan dikaitkan dengan potensi tindak kejahatan (Perkins et al., 1992) seperti yang terlihat pada Gambar 11.

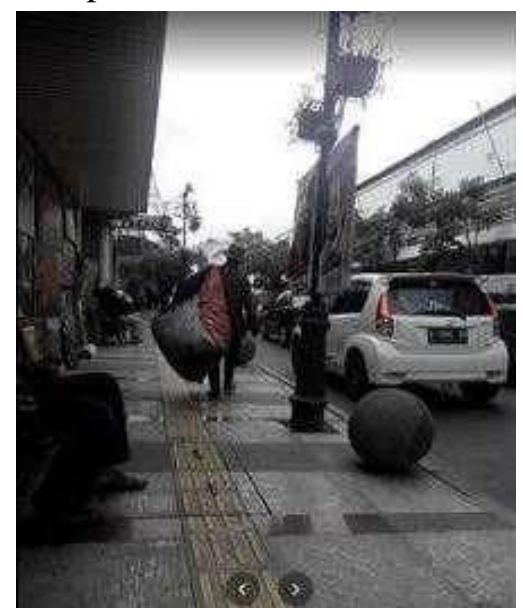

(a)

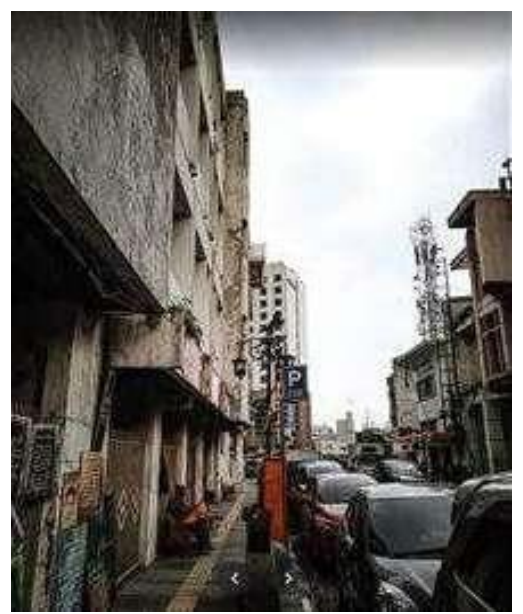

(b)

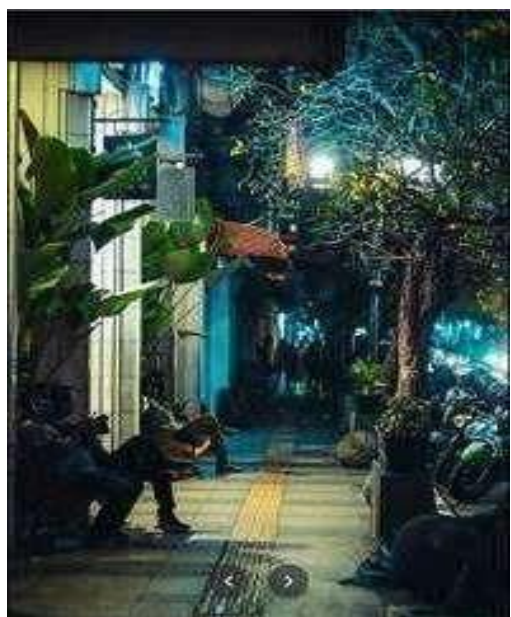

(c)

Gambar 11. Pengguna Jalan (a) Pemulung, (b) Tukang parkir, (c) Kelompok Pria Sumber: Google Maps, 2020

\subsubsection{Comfort}

Comfort mengacu pada kenyamanan, kemudahan dan kepuasan seseorang. Kepuasan seseorang terhadap pengalaman berjalan dipengaruhi oleh kualitas lingkungan yang memfasilitasi aktivitas berjalan atau dengan menghilangkan faktor-faktor yang dapat membuat perjalanan menjadi tidak nyaman. (Alfonzo, 2005).

Salah satu kualitas yang mempengaruhi comfort jalan adalah hubungan antara pedestrian dan kendaraan bermotor. Di sepanjang jalan yang diteliti terdapat perbedaan tekstur antara jalur pedestrian dan jalur kendaraan bermobil. Terdapat pula perbedaan ketinggian antara kedua jalur tersebut, yang mempertegas batas 
antara kedua jalur (Gambar 12).

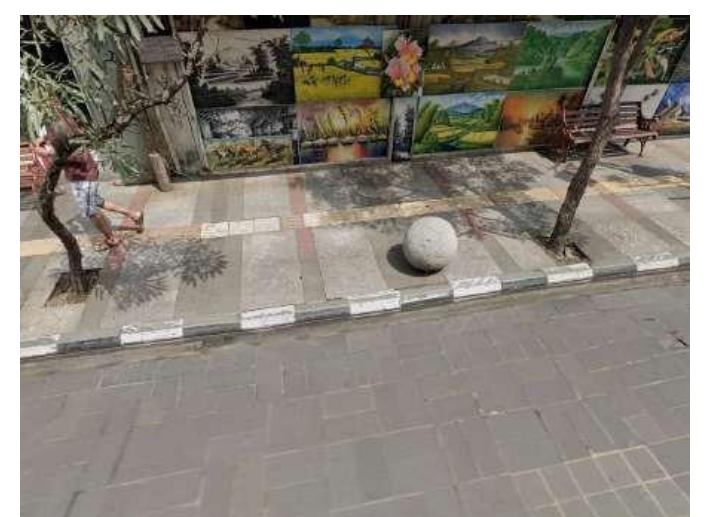

\section{Gambar 12. Perbedaan Tekstur Pada Jalur Pedestrian dan Jalur Kendaraan Bermobil} Sumber: Google Street View, 2019

Kualitas lainnya adalah karakteristik desain terkait dengan sistem jalur pejalan kaki dan jaringan jalan. Lebar dari jalur pedestrian mempengaruhi kualitas jalan. Jalur pedestrian di Jalan Braga memiliki lebar 2 meter. Di sepanjang jalur tersebut tersebar beton bollard bulat yang menjadi buffer untuk jalur pedestrian sehingga meningkatkan keamanan pedestrian. Di sepanjang Jalan Braga juga tersebar vegetasi dalam pot kotak yang berfungsi sebagai buffer jalur pedestrian dan menambah unsur hijau pada jalan. Vegetasi yang akarnya tertanam di tanah menambah kenyamanan pedestrian dengan membuat jalan tampak lebih nyaman dan memberikan peneduh bagi pejalan kaki (Gambar 13).

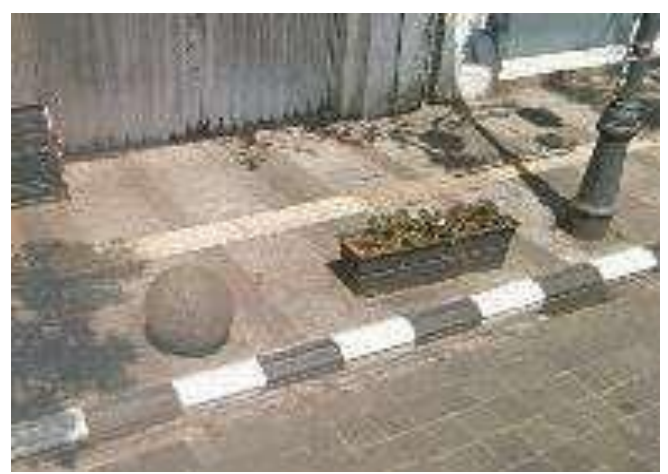

(a)

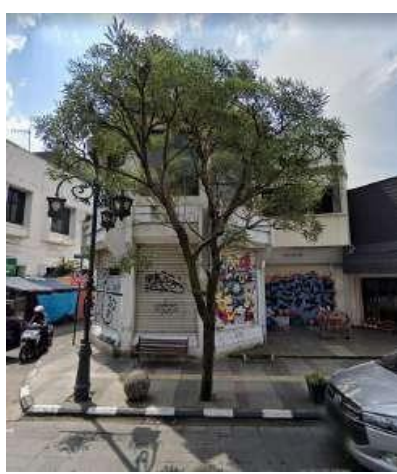

(b)

Gambar 13. (a) Beton Bollard Bulat dan Pot Vegetasi, (c) Vegetasi Sumber: Google Street View, 2019

Keberadaan fasilitas jalan juga mempengaruhi kenyamanan para pejalan kaki. Fixture seperti kursi yang tersebar di sepanjang Jalan Braga dapat digunakan oleh pedestrian untuk beristirahat atau duduk duduk menikmati kondisi jalan. Keberadaan elemen yang menawarkan perlindungan dari kondisi cuaca yang tidak menguntungkan seperti hujan atau terik matahari juga mempengaruhi kualitas dari jalan. Terdapat keberadaan beberapa kanopi dari bangunan-bangunan di sisi Jalan Braga memberikan perlindungan bagi pedestrian dari cuaca (Gambar 14 dan 15).
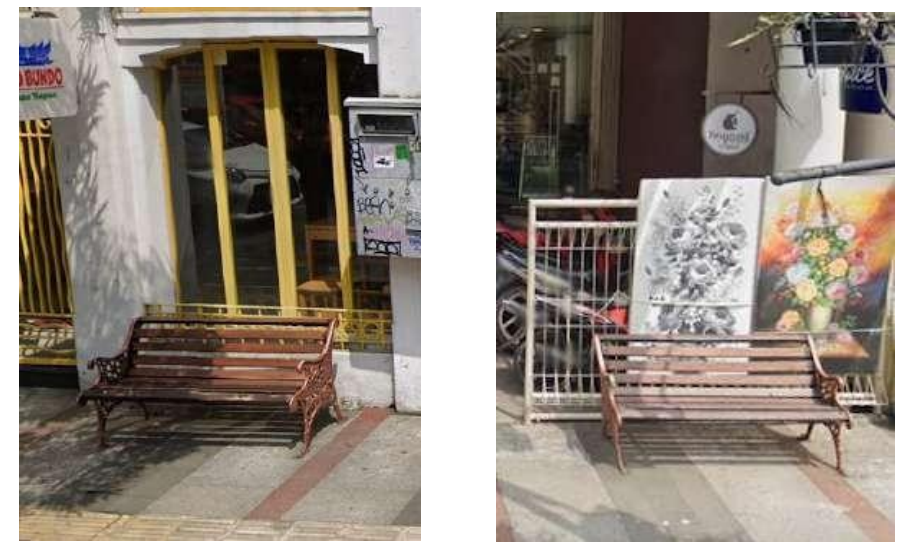

Gambar 14. Kursi di Beberapa Titik Jalan

Sumber: Google Street View, 2019 

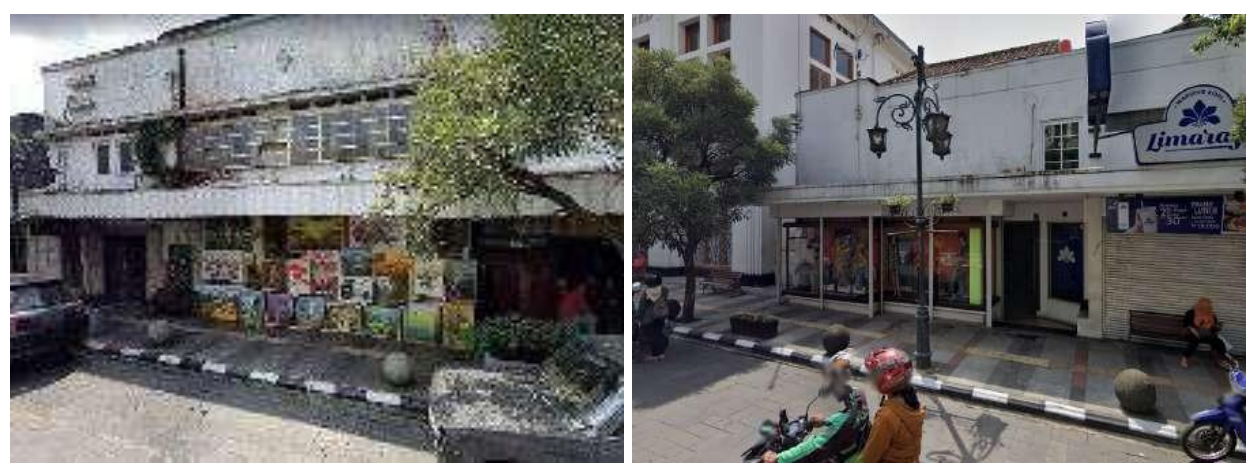

Gambar 15. Kanopi di Beberapa Titik Jalan

Sumber: Google Street View, 2019

\subsubsection{Pleasurability}

Pleasurability atau kenikmatan adalah tingkat tertinggi dari konsep hierarki kebutuhan pejalan kaki. Keragaman, kompleksitas, keaktifan, skala, koherensi arsitektural, dan estetika adalah faktor-faktor yang mempengaruhi aspek ini. Faktor-faktor ini dapat diaplikasikan melalui keberagaman streetscape, fungsi campuran, elemen-elemen arsitektural, arsitektur historis, ruang-ruang publik, kehadiran orang-orang, vendor jalan atau pedagang kaki lima, area makan di luar, dan lain-lain.

Karakter Jalan Braga yang memiliki Garis Sempadan Bangunan (GSB) 0 meter memberikan daya tarik tersendiri pada walking experience para pejalan kaki. Hal tersebut dikarenakan, pejalan kaki dapat menyaksikan berbagai macam aktivitas dalam ruangan dari trotoar sepanjang Jalan Braga. Area outdoor yang dimiliki oleh pertokoan, area publik di sepanjang jalan, dan keberadaan Pedagang Kaki Lima (PKL) membuat ruang di sepanjang trotoar menjadi hidup. Aktivitas beragam yang ada di sepanjang jalan ini menciptakan Street experience yang menarik bagi pejalan kaki (Gambar 16 s.d. 21)

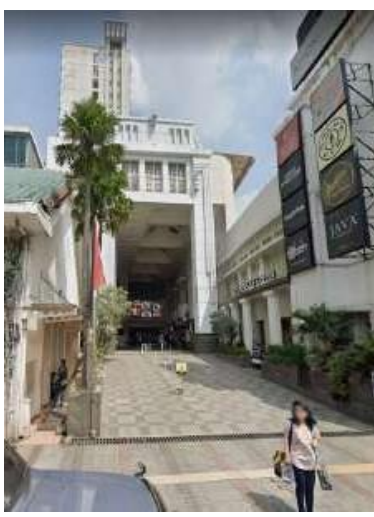

(a)

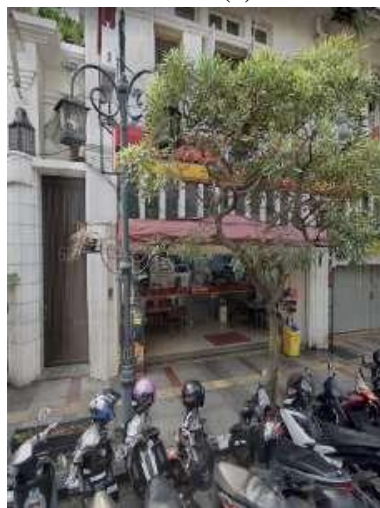

(e)

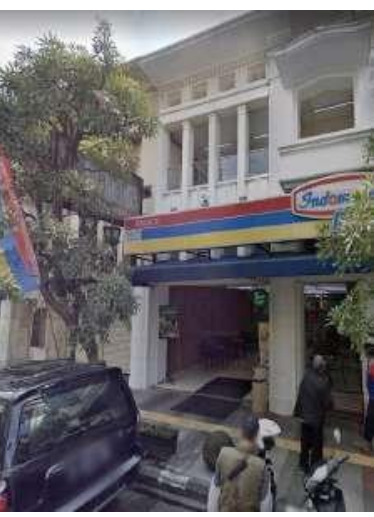

(b)

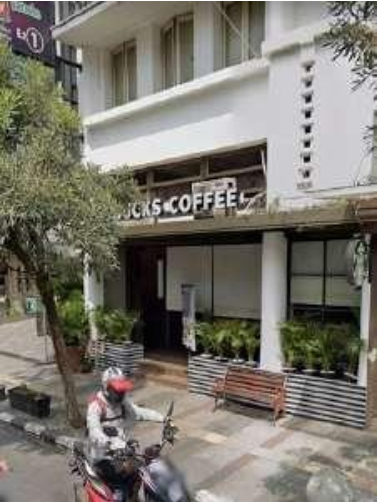

(f)

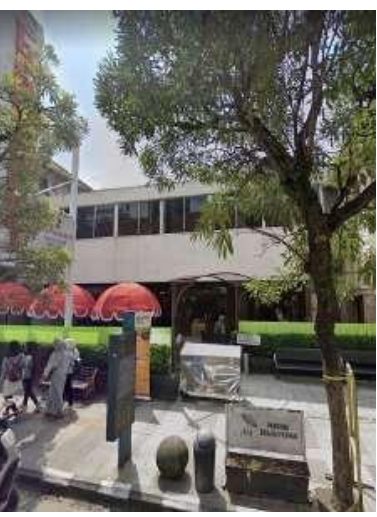

(c)

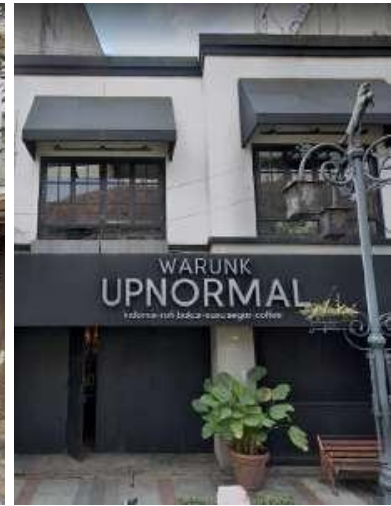

(g)

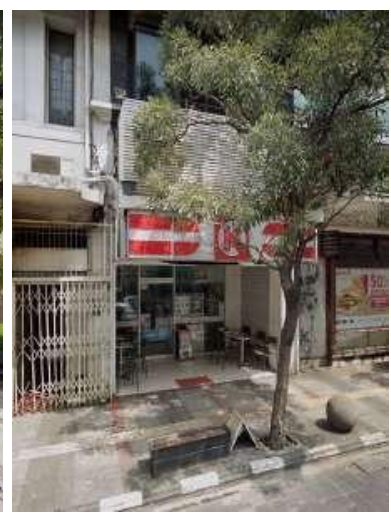

(d)

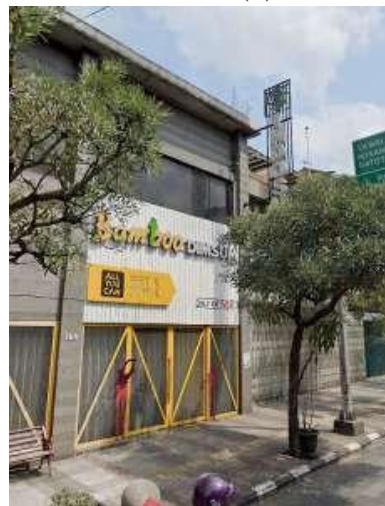

(h)

Gambar 16. Toko-Toko Yang Mempunyai Area Outdoor (a) Gino Feruci Braga Hotel, (b) Indomaret, (c) Braga Permai Restaurant, (d) Circle K, (e) Alfamart, (f) Starbucks, (g) Warunk Upnormal, (h) Myloc Coffee and Cafe Sumber: Google Street View, 2019 


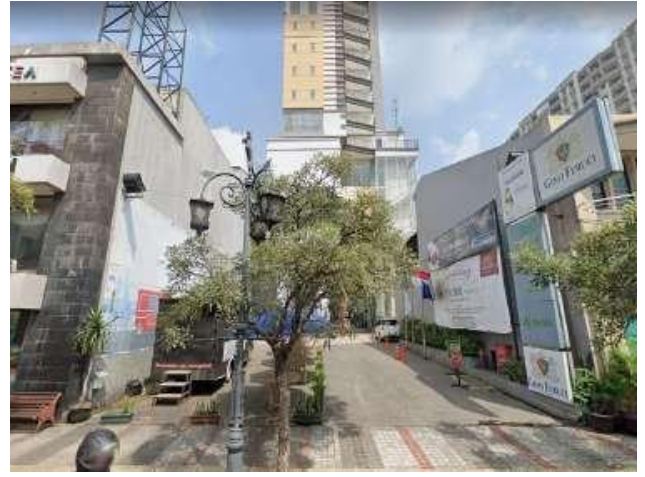

(a)

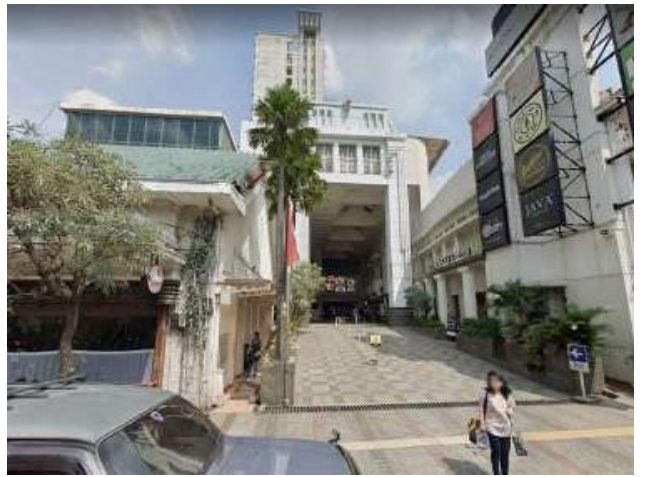

(b)

Gambar 17. Suasana Area Outdoor Pertokoan (a) Gino Feruci Braga Hotel, (b) Braga Permai Permai Sumber: Google Street View, 2019

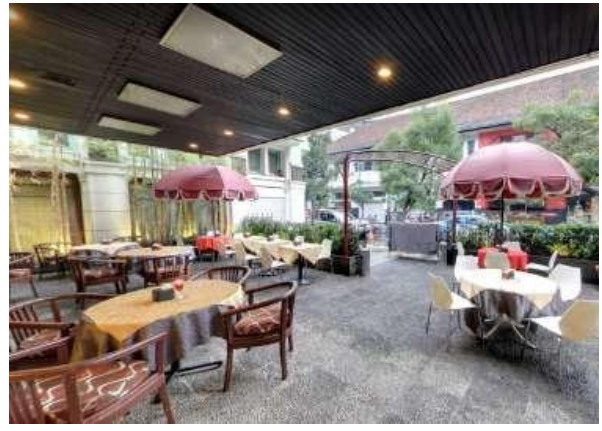

(a)

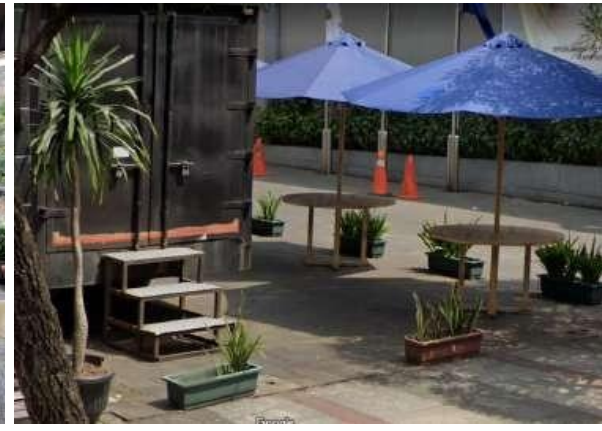

(b)

Gambar 18. Area Berkumpul (a) Geno Feruci Hotel, (b) Braga Mall Sumber: Google Street View, 2019

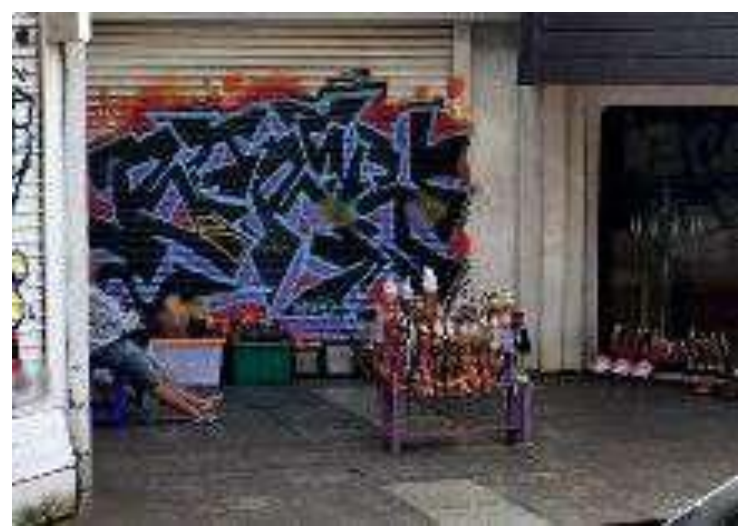

Gambar 19. PKL yang Menjual Mainan Anak Sumber: Google Street View, 2019

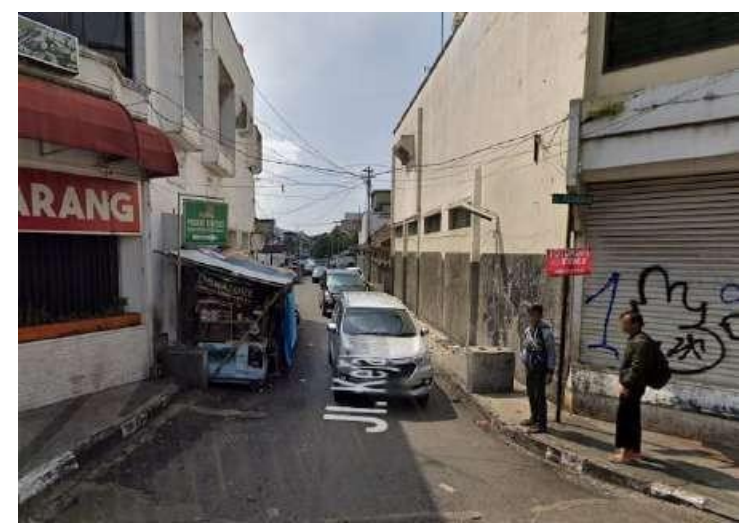

Gambar 20. PKL di Persimpangan Jalan Kejaksaan Sumber: Google Street View, 2019 


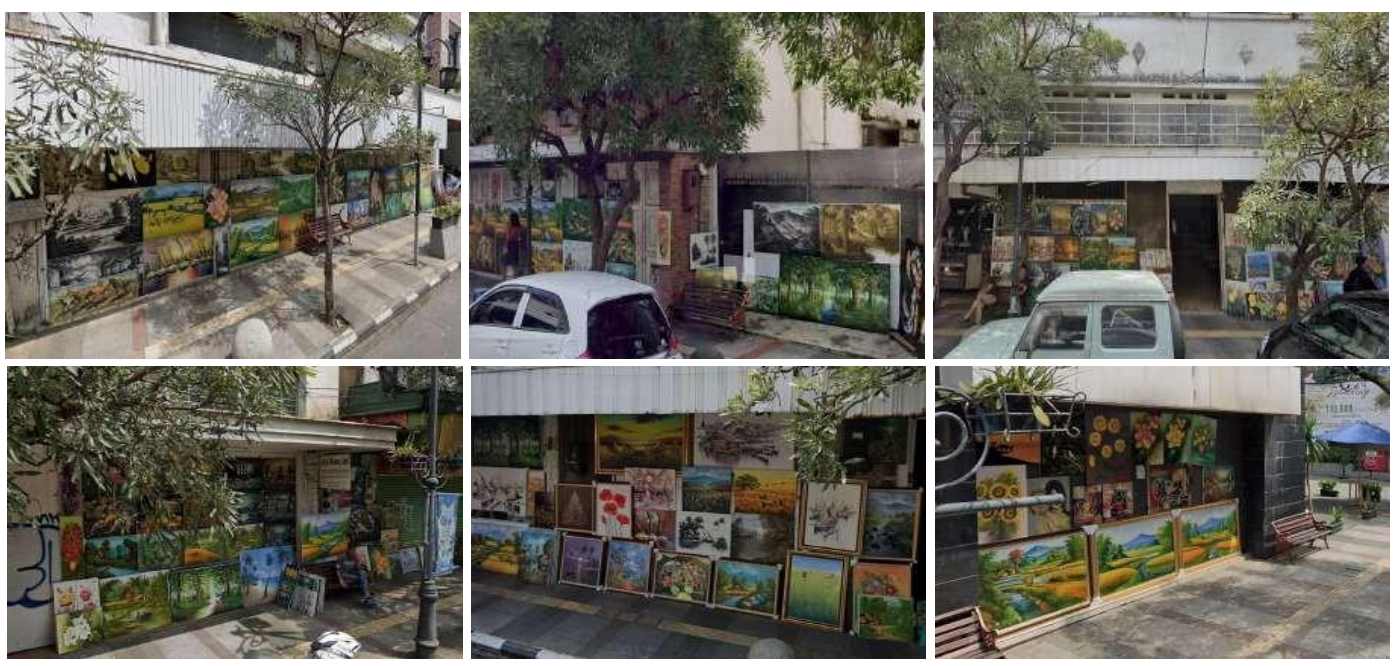

Gambar 21. Penjual Lukisan di Sepanjang Trotoar

Sumber: Google Street View, 2019

Area-area outdoor pada pertokoan merupakan fasilitas khusus untuk pengunjung toko. Terdapat 9 toko di sepanjang jalan yang memiliki area outdoor. Bangunan di sepanjang Jalan Braga pada umumnya memiliki GSB 0 meter, namun ada beberapa bangunan yang dimundurkan, seperti Geno Feruci Hotel dan Braga Mall. Entrance kedua bangunan ini yang jauh dari jalan pedestrian menciptakan ruang publik untuk berkumpul di depan bangunan tersebut. Selain itu, aktivitas-aktivitas yang ditemukan di sepanjang jalan antara lain PKL yang berjualan mainan anak, PKL yang berjualan makanan di persimpangan Jalan Kejaksaan, dan para penjual lukisan yang cukup banyak terutama di bagian selatan Jalan Braga.

Streetscape di sepanjang Jalan Braga terbentuk oleh bangunan-bangunan bergaya Art Deco peninggalan arsitektur kolonial dan fitur-fitur jalur pedestrian yang dibahas pada aspek comfort. Beberapa bangunan ini telah mengalami kerusakan dan dibangun kembali dengan gaya modern, hal ini menciptakan keanekaragaman langgam dan artikulasi bangunan di sepanjang jalan. Jalan ini juga memiliki kurang lebih 53 toko di sepanjang jalannya dengan fungsi berbeda-beda seperti toko makanan, kantor, bank, restoran, bar, dan cafe. Selain itu, kesan historis Jalan Braga masih terjaga dengan adanya pengakuan dan perawatan bangunan-bangunan heritage di sepanjang jalannya. Bangunan-bangunan ini mengandung unsur kebudayaan dan historis yang bernilai tinggi. Keberadaan bangunan-bangunan heritage memberikan keunikan, ketertarikan, dan nilai lebih dalam street experience Jalan Braga (Gambar 22 dan 23).

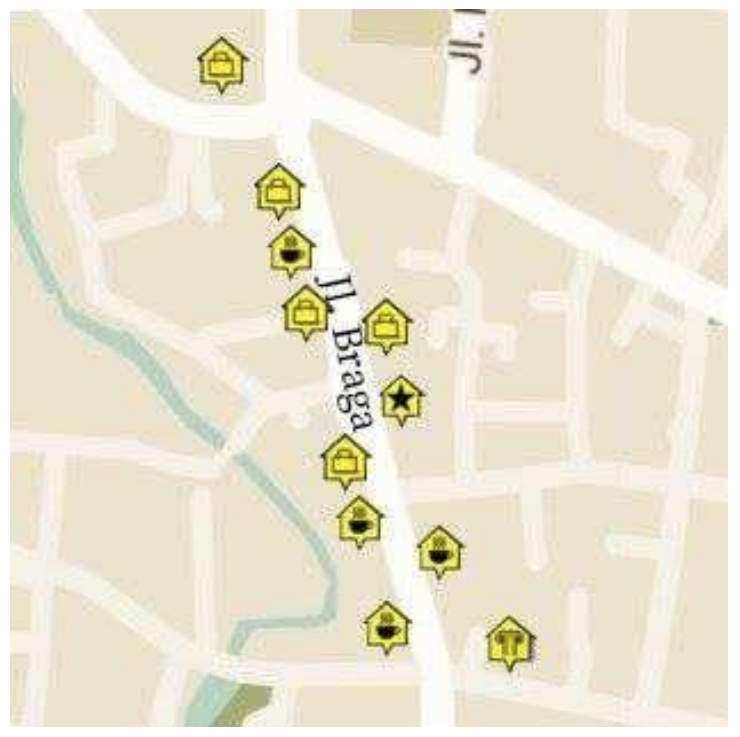

Gambar 22. Bangunan-Bangunan Heritage yang Tersebar di Jalan Braga

Sumber: Google My Maps WarisanBandung_Heritage, 2019 


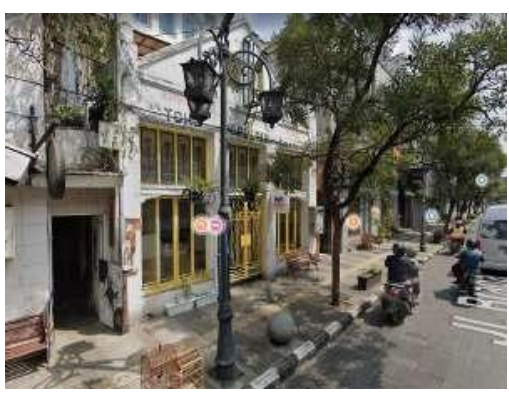

(a)

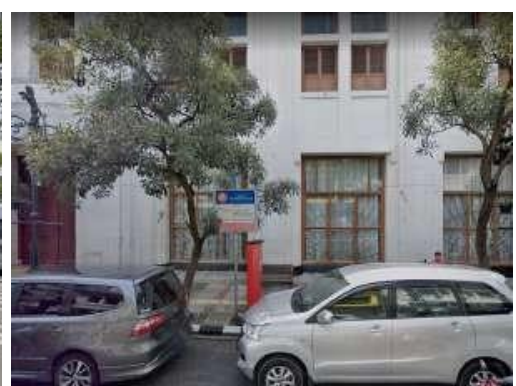

(b)

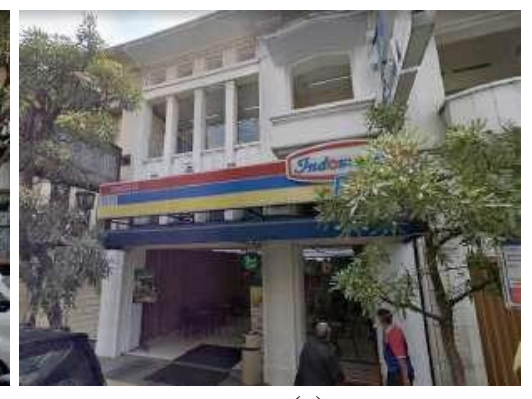

(c)

Gambar 23. Bangunan-Bangunan Heritage di Jalan Braga (a) Toko Popular (sekarang Warung Kopi

'Kopitiam'), (b) Gedung Gas Negara, (c) Ruko Kellers (sekarang Indomaret)

Sumber: Google Street View, 2019

\section{Kesimpulan}

Dari hasil penelitian ini, didapatkan temuan-temuan berupa:

1. Feasibility atau kelayakan merupakan aspek internal pejalan kaki seperti umur, jenis kelamin, beban aktivitas, kebiasaan berjalan. Faktor-faktor ini tidak dipengaruhi oleh streetscape.

2. Accessibility atau aksesibilitas mengacu pada derajat kemudahan yang dicapai seseorang terhadap suatu objek, pelayanan, maupun lingkungan. Trotoar Jalan Braga yang memiliki kontinuitas yang konsisten memudahkan para pengunjung untuk bermobilisasi di sepanjang jalan tersebut. Jeda pada trotoar yang disebabkan oleh adanya persimpangan jalan juga sudah memiliki pembatas dan tanda yang jelas, seperti perbedaan ketinggian trotoar dan jalan kendaraan; adanya kanstin; dan simbol berhenti pada guiding block

3. Safety atau keselamatan merupakan perasaan aman dari tindakan kejahatan. Unsur grafiti, bangunan tidak terpakai, kelompok atau individu yang mengancam dapat ditemukan di Jalan Braga. Unsur-unsur ini hanya menciptakan kesan tidak aman yang berbeda-beda bagi setiap individu pengguna jalan. Pengelola Jalan Braga dapat meminimalisir kesan tersebut dengan memperhatikan unsur-unsur tersebut, sementara untuk pejalan kaki dapat memilih untuk berkunjung dalam kelompok.

4. Comfort atau kenyamanan dipengaruhi oleh kualitas lingkungan yang akan memberikan dampak kepada kepuasaan seseorang terhadap pengalaman berjalannya. Pada Jalan Braga hubungan antara jalur pedestrian dan jalur kendaraan bermotor terlihat jelas dengan perbedaan ketinggian dan tekstur. Karakteristik desain jalan juga menunjang kenyamanan dengan penyediaan buffer berupa beton bollard bulat dan pot kotak. Vegetasi pada pot kotak menambah unsur hijau jalan. Vegetasi yang tertanam di tanah membuat jalan tampak lebih nyaman dan memberikan peneduh bagi pejalan kaki. Keberadaan fasilitas jalan di sepanjang jalan braga seperti kursi dan kanopi dari bangunan juga memberikan kenyamanan bagi pejalan kaki.

5. Pleasurability atau kenikmatan dapat dicapai melalui keaktifan, keragaman, kompleksitas, koherensi arsitektural, dan estetika Pertokoan-pertokoan yang memiliki outdoor area, tempat berkumpul di trotoar yang tercipta dari bangunan yang dimundurkan, dan keberadaan pedagang kaki lima menambahkan keaktifan dan kehidupan di sepanjang Jalan Braga. Keberadaan bangunan-bangunan heritage dan fungsi campuran menciptakan keberagaman streetscape di sepanjang jalan sehingga memberikan ketertarikan dan keunikan dalam street experience Jalan Braga.

Dari temuan-temuan tersebut, dapat ditarik kesimpulan bahwa semua kebutuhan pejalan kaki berdasarkan elemen-elemen visual streetscape Jalan Braga sudah terpenuhi, namun pengelolaannya dapat ditingkatkan kembali untuk menciptakan kualitas street experience Jalan Braga yang lebih baik. Pemanfaatan teknologi zaman kini yang disajikan lewat wadah Google Street View dapat memberikan sensasi pengalaman jelajah virtual baru yang sejatinya dapat dikembangkan dan dipergunakan lebih lanjut untuk penelitian maupun perkembangan berbagai aspek kota dan perencanaan.

\section{Referensi}

Alfonzo, M. A. (2005). To walk or not to walk? The hierarchy of walking needs. Environment and Behavior. https://doi.org/10.1177/0013916504274016

Amalia, A.N., and Ekomadyo, A.S. (2018). Connecting Global Market and Local Potential through Designing Heritage Port Case: International Cruise Port in Probolinggo. The 4th Biennale International Conference on Indonesian Architecture and Planning (ICIAP): Design and Planning in the Disruptive Era. Gadjah Mada University Yogyakarta Indonesia, July 26-28 2018.

Carmona, M., Heath, T., Oc, T., Tiesdell, S. (2003). Public place urban spaces: The dimensions of urban 
design. Architectural Press.

Cesarin, B.T., Hanan, H., Ekomadyo, A.S. (2017) Urban Design Dimension of Informality at The Perimeter of Brawijaya University and UIN Maliki Malang. International Conference of Architectural Education in Asia (Eduarchsia), Indonesian Islamic University, Yogyakarta, November 9, 2017, https://doi.org/10.1051/shsconf/20184107005

Crankshaw, Ned. (2015). Creating vibrant public spaces: Streetscape design in commercial and historic districts. Island Press.

Ekomadyo A S. (2018) Membaca Ruang Kota Sebagai Tempat Rajutan Budaya Kasus: Keseharian Pertokoan Tua Pada Kluster Permukiman Kolonial Di Bandung. Prosiding Seminar Kota LayakHuni. Universitas Trisakti Jakarta, $22 \quad$ Februari 2018. http://www.trijurnal.lemlit.trisakti.ac.id/index.php/lslivas/article/view/2748

Ekomadyo, A.S., Santri, T., Resmadi, I., AlMubarok, H. (2016). Conversation Between Trade and Mysticism: Exercising Design as Mediator to Link Economic and Culture in Kampung Batik Trusmi Cirebon. International Seminar of Vernacular Settlement-8: Conversation with the Sea: People, Places, and Ideas of Maritime Vernacular Settlement. Hassanuddin University, Gowa-Makassar, October 20-22, 2016.

Ekomadyo, A.S., Nurfadillah, A., Kartamihardja, A., Cungwin, A.J. (2018). Becoming Heritage: A PlaceMaking Study of Old Neighbourhood Marketplace in Bandung. The 4th PlanoCosmo International Conference, Transforming beyond Borders: Starting the New Urban Agenda. Institut Teknologi Bandung, Bandung, April 2-4, 2018. IOP Conf. Series: Earth and Environmental Science 158 (2018) 012012 doi : 10.1088/1755-1315/158/1/012012

Gehl, J. (1987). Life between the buildings : using public space. In Life between the buildings : using public space. Island Press.

Gilge C. (2016). Google Street View and the Image as Experience. GeoHumanities 2(2):1-16.

Hernowo, B. (2015). Mengapa Bangunan Heritage Sangat Penting Untuk Kota Kita? ResearchGate, June. https://doi.org/10.13140/RG.2.1.1653.7762

Kogarah City Council. (2006). Section 94 Contribution Plan No. 8 Kogarah Town Centre. Kogarah City Council.

Panjaitan, I., Yasin, M.P.E, Ekomadyo, A.S. (2017). Singosaren As Interactive Space In Kotagede Tourism Destination. International Conference of Architectural Education in Asia (Eduarchsia), Indonesian Islamic University, Yogyakarta, November 9, 2017, https://doi.org/10.1051/shsconf/20184104008

Perkins, D. D., Meeks, J. W., \& Taylor, R. B. (1992). The physical environment of street blocks and resident perceptions of crime and disorder: implications for theory and measurement. Journal of Environmental Psychology. https://doi.org/10.1016/S0272-4944(05)80294-4

Rubenstein, Harvey M. 1992. Pedestrian Malls, Streetscapes, and Urban Spaces. John Wiiley and Sons.

Rundle, A. G., Bader, M. D. M., Richards, C. A., Neckerman, K. M., \& Teitler, J. O. (2011). Using google street view to audit neighborhood environments. American Journal of Preventive Medicine. https://doi.org/10.1016/j.amepre.2010.09.034

Siregar, H.H., Natalivan, P., Ekomadyo, A.S. (2017). Cultural Assemblage As Genius Loci: Character Analysis Of Medan City Center District. International Conference of Architectural Education in Asia (Eduarchsia), Indonesian Islamic University, Yogyakarta, November 9, 2017, https://doi.org/10.1051/shsconf/20184104011

Tsai, V.J.D. \& Chang, C.T. (2012). Feature Positioning on Google Street View Panoramas. ISPRS Annals of the Photogrammetry, Remote Sensing and Spatial Information Sciences 1(4): 305-309

Yin, L., Cheng, Q., Wang, Z., \& Shao, Z. (2015). "Big data" for pedestrian volume: Exploring the use of Google Street View images for pedestrian counts. Applied Geography, 63, 337-345. https://doi.org/10.1016/j.apgeog.2015.07.010 